\title{
Effect of aqua-drugs and chemicals on shrimp health and production in Khulna, Bangladesh
}

\author{
MD. JAHID HOSSAIN, GIAS UDDIN AHMED ${ }^{1, *}$, MD. MAMNUR RASHID ${ }^{1}$, \\ SHAHRINA AKHTAR ${ }^{2}$ AND M. MAMUNUR RAHMAN ${ }^{1}$ \\ Department of Aquaculture, Khulna Agricultural University, Daulatpur 9202, Khulna, Bangladesh, \\ ${ }^{1}$ Department of Aquaculture, Bangladesh Agricultural University, Mymensingh 2202, Bangladesh, \\ ${ }^{2}$ Department of Environment Science and Management, Independent University of Bangladesh, Dhaka \\ *Corresponding Author: giasa50@gmail.com
}

\begin{abstract}
Present study was conducted in three different Upazilas viz., Batiaghata, Dacope and Rupsha of Khulna district, Bangladesh from August 2016 to May 2017. Data were collected through personal contact, farms and market survey and discussion with shrimp farmers and drug sellers. Farmers of the research areas used Oxolinic acid, Renamucin, Oxytetracucline, Lime, Salt, Formalin, Eco-solution, Basudin and Timsen to treat the viral, bacterial and fungal diseases. Average recovery of $55-60 \%$ and $35-40 \%$ were recorded from bacterial and fungal diseases of shrimp respectively, but there was no recovery in case of viral diseases. Shrimps of nontreated ghers were affected by WSSV, Black gill disease, Black spot disease, Zoothumnium and external fouling but almost no disease were observed in aqua drugs-treated ponds. Histological findings showed that shrimp muscles and hepatopancreas in drug treated ponds and ghers had some pathological changes like necrosis, vacuums and hemorrhages which were severe in winter season, whereas, normal structure of muscle and hepatopancreas were observed during summer season. Production of shrimp in the study areas was recorded $6916 \mathrm{Kg} / \mathrm{ha}$ in probiotics and aqua-drugs treated ponds, whereas, $543 \mathrm{Kg} / \mathrm{ha}$ in nontreated ghers. From the present study it could be concluded that aqua-drugs and chemicals have positive effect on shrimp health and production except some pathological changes in the investigated organgs of shrimp especially during winter season.

Keywords: Aqua-drugs, Shrimp health, Khulna region
\end{abstract}

\section{Introduction}

Coastal aquaculture is an old practice in Bangladesh, but from early seventies when demand and price of shrimp in the world market increased, much emphasis has been given on culture of bagda shrimp (Penaeus monodon) rather than fin fishes. Coastal aquaculture farms are mostly located in Bagerhat (29\%), Satkhira (19\%), Khulna (19\%), and Cox's Bazar (33\%) (Banglapedia 2014). In Bangladesh the production of aquaculture is increasing day by day through diversification (Mahmud et al. 2012, Ahmed et al. 2012). Major aquaculture relies heavily on the input of formulated feeds and the application of agrochemicals, antibiotics and other aqua drugs (Sharker et al. 2014). For successful aquaculture technology is most needed (Subasinghe et al. 1996) as well as the application of different aqua-drugs and chemicals which enhance production and disease resistance capacity of fish and shrimp (Hasan et al. 2015). A variety of aqua-drugs and chemicals are used in both coastal and inland aquaculture. The purpose of using chemicals and antibiotics are to improve health condition of aquatic animals, growth promotion (Ahmed et. al. 2012), feed formulation, manipulation of production, transportation of live fish, pond construction and overall management of pond environment and water quality (Faruk et al. 2004 and Khan et al. 2011). Some common chemicals are used for health management including sodium chloride, formalin, malachite green, methylene blue, potassium permanganate and hydrogen peroxide (Plumb 1992). Recently some farmers use

https://doi.org/10.52168/bjf.2021.33.11 
probiotics such as AQ cell, AQ grow G, Aquamin, Cevit vet, Megavit aqua, Acemix super fish, Aqua Boost, Rapid Grow, Hepaprotect-Aqua for fish growth and health management (Ahmed et al. 2015). In most of the cases the farmers do not maintain the appropriate dose of drugs for environment and disease treatment. However, indiscriminate use of aqua-drugs and chemicals often lead to problems like drug resistance, tissue residues, adverse effect on species biodiversity etc., which ultimately affect the cultured species, human and environment (Ahmed et.al. 2012). Different types of disease could be found in farmed aquatic animals in Bangladesh (Karim and Stellwagen 1998, BFRI 1999, Faruk et al. 2004). Major diseases of shrimp included cramped tail, soft shell, black spot, early mortality syndrome (EMS) or acute hepatopancreatic necrosis disease (AHPND), White spot syndrome (WSSV) and yellow head disease (YHD). EMS is a fairly new and non-viral disease caused by bacterial agent Vibrio parahaemolyticus that affects shrimp health (Stentiford et al. 2006). Clinical and histological knowledge is vital to determine health status of shrimp. Thus the present investigation was carried to focus aqua drugs and chemicals on shrimp health especially disease treatment and production through clinical, histological and general field perception in Khulna region.

\section{Materials and Methods}

Study area: The study was carried out from August 2016 to May 2017. The sampling locations were Dacope and Batiaghata in Khulna district and Rupsha in Bagherhat district. These areas were selected as they contribute substantially to shrimp production, where aqua drug sellers and representatives of pharmaceutical companies were frequent.

Data collection: Data were collected through questionnaire interview with shrimp farmers, market survey and retailers of aqua-drugs and chemicals. For questionnaire interview a set of questionnaire was prepared which was composed of both closed and open form of questions. Individual interviews were carried out from the farmers through randomly personal contact. A total of 40 farmers (12 to 15 farmers from each sampling areas) were personally interviewed. A sum of 29 drug sellers was interviewed with 8 to 5 drug sellers and traders from each area (Table I).

Table I. Sample size of target groups in the study areas

\begin{tabular}{l|l|l|c}
\hline Name of districts & Sampling area & Target groups & Sample size \\
\hline \multirow{4}{*}{ Khulna } & Batiaghata & Farmers & 13 \\
\cline { 3 - 4 } & & Drug sellers & 05 \\
\cline { 2 - 4 } & \multirow{2}{*}{ Dacope } & Farmers & 12 \\
\cline { 3 - 4 } & & Drug sellers & 06 \\
\cline { 2 - 4 } & \multirow{2}{*}{ Rupsha } & Farmers & 15 \\
\cline { 3 - 4 } & & Drug sellers & 08 \\
\hline
\end{tabular}

Sample collection: The samples were collected from the field level. Clinical signs of the shrimps were examined by naked eye to observe any injury, infection and other abnormal conditions of the shrimp body. For histological observation, samples of hepatopancreas and muscle collected farm wise and season wise. Muscle samples were collected from the middle portion of shrimp and fixed in Devidson fixative and kept in transparent plastic vials. Then 
samples were dehydrated, cleaned and infiltration through an Automatic Tissue Processor (SHADON, Citadel 1000), sectioned and stained with hematoxylin and eosin. The sections were examined under a compound photomicroscope.

\section{Results}

Clinical observations of shrimps in the study areas: Clinically shrimp appeared normal grayish and healthy in drugs and chemical treated pond during summer (Fig. 1). Shrimps were normal and healthy with slight yellow-greenish color during autumn season. Most of the shrimps were affected by diseases like EMS, WSSV, YHD, Black gill disease, Fouling, Reddish discoloration, cramped body, Black shell disease and also bad odor due to algal bloom in rainy and winter seasons.
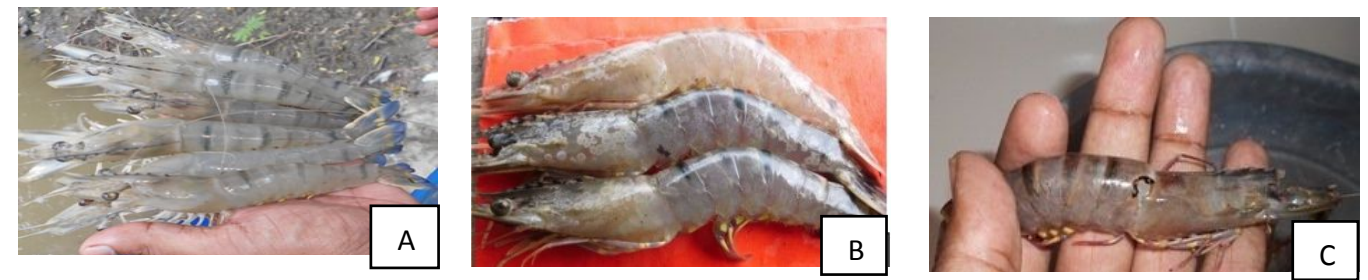

Fig. 1. Clinical appearance of shrimp in different regions from drugs treated ponds and non-treated ghers in coastal areas. A) Apparently healthy shrimp, B) WSSV affected shrimp and C) Shrimp affected by black shell disease.

In Khulna region farmers used different types of drugs for the treatment of viral, bacterial and protozoan diseases. There are no treatments for White Spot Disease (WSD) and Yellow Head Disease (YHD), though the farmers used Malachite green, Methylene blue, Bleaching powder and Potassium permanganate $\left(\mathrm{KMnO}_{4}\right)$ for the treatment of WSD but had no recovery, however, Potassium permanganate $\left(\mathrm{KMnO}_{4}\right)$, Eco solution, Methylene blue, Basudin and Timsen had an average of $15-20 \%$ recovery on YHD (Table II). Farmers used Renamycin, Oxytetracycline, lime, salt, and potassium permanganate for the treatment of bacterial diseases which had an average of 55-60\% recovery. Farmers used Formalin, Oxolinic acid, Sarafloxacin, Renamycin, Oxytetracycline, lime and salt which had an average of $35-40 \%$ recovery on cotton shrimp disease but had no positive impact on black gill disease (Table II).

\section{Histological observations of shrimp from study areas}

Observations of shrimp muscle: Observations of section of muscle of shrimp from Botiaghata, Dacope and Rupsha was normal in summer season (Figs. 2, 3 and 4) however, there were some vacuums, hemorrage and necrosis in muscle of shrimp in the rainy season. In the autum season muscle of shrimps were almost normal in all the study areas. In winter season muscle of shrimp had severe pathologies like vacuums, hemorraghe and necrosis in Botiaghata, Dacope and Rupsha (Figs. 5, 6 and 7).

Observations of hepatopancreas of shrimp: Hepatopancreas of shrimp were normal during summer season (Figs. 8, 9 and 10) from the non treated ponds. There were some pathological changes like vacuums, necrosis and hemorrhage from Botiaghata, Dacope and Rupsha during 
rainy season. During autum season the hepatopancreas of shrimp were almost normal with mild vacuums in Botiaghata and Dacope. There were severe vacuums, necrosis and hemorrhage in hepatopancreas from study areas (Figs 11, 12 and 13) during winter season from the drug treated ponds.

Table II. Effect of aqua-drugs and chemicals on shrimp diseases

\begin{tabular}{|c|c|c|c|c|}
\hline $\begin{array}{c}\text { Study } \\
\text { area }\end{array}$ & $\begin{array}{c}\text { Suspected } \\
\text { disease }\end{array}$ & Symptoms & Drugs and chemicals with dose & $\begin{array}{c}\text { Recovery } \\
\text { rate }(\%)\end{array}$ \\
\hline \multirow{6}{*}{$\begin{array}{l}\text { Khulna } \\
\text { region }\end{array}$} & $\begin{array}{l}\text { White Spot } \\
\text { Disease } \\
\text { (WSD) }\end{array}$ & $\begin{array}{l}\text { White spots or patches, } \\
\text { on the inside of the shell } \\
\text { and carapace. }\end{array}$ & $\begin{array}{l}\text { Malachite green } 10 \mathrm{~g} / \mathrm{dec} \\
\text { Methylene blue } 10 \mathrm{~g} / \mathrm{dec} \\
\text { Bleaching powder } 60 \mathrm{ppm} \\
\mathrm{KMnO}_{4} 0.1-0.2 \mathrm{ppm}\end{array}$ & 0 \\
\hline & $\begin{array}{l}\text { Yellow Head } \\
\text { Disease } \\
(\text { YHD) }\end{array}$ & $\begin{array}{l}\text { Pale bodies, a swollen } \\
\text { cephalothorax with a } \\
\text { light yellow to yellowish } \\
\text { hepatopancreas. }\end{array}$ & $\begin{array}{l}\mathrm{KMnO}_{4} 0.1-0.2 \mathrm{ppm} \\
\text { Eco solution } 0.1-0.2 \mathrm{ppm} \\
\text { Methylene blue } 10 \mathrm{~g} / \mathrm{dec} \\
\text { Basudin } 150 \mathrm{~g} / 33 \mathrm{dec} \\
\text { Timsen } 80 \mathrm{~g} / 33 \mathrm{dec}\end{array}$ & $15-20$ \\
\hline & Vibriosis & \begin{tabular}{llr}
\multicolumn{2}{l}{ Reddish discoloration of } \\
juvenile & shrimp, & black \\
spots, & chronic & soft \\
shelling. & &
\end{tabular} & $\begin{array}{l}\text { Renamycin } 5 \mathrm{~g} / \mathrm{kg} \text { feed } \\
\text { Oxytetracycline } \quad 1 \mathrm{~g} / \mathrm{kg} \quad \text { feed } \\
\text { Lime } 0.5-1 \mathrm{~kg} / \mathrm{dec} \\
\text { Salt } 0.5-1 \mathrm{~kg} / \mathrm{dec} \\
\mathrm{KMnO}_{4} 0.1-0.2 \mathrm{ppm}\end{array}$ & $55-60$ \\
\hline & $\begin{array}{l}\text { Black Gill } \\
\text { Disease }\end{array}$ & $\begin{array}{l}\text { Brownish to blackish } \\
\text { discoloration on the gills } \\
\text { of juvenile shrimp. }\end{array}$ & 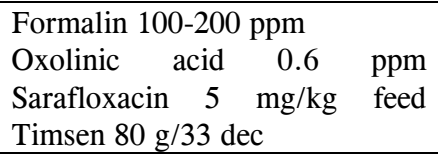 & 0 \\
\hline & $\begin{array}{l}\text { Cotton shrimp } \\
\text { disease or Milk } \\
\text { shrimp disease }\end{array}$ & $\begin{array}{l}\text { Infected shrimps appear } \\
\text { opaque and cooked. } \\
\text { Gradual and low levels of } \\
\text { mortalities are observed. }\end{array}$ & 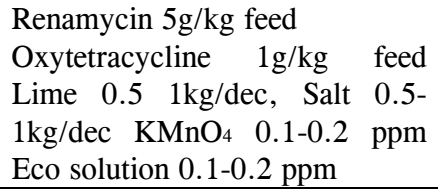 & $35-40$ \\
\hline & $\begin{array}{l}\text { Surface Fouling } \\
\text { Diseases }\end{array}$ & $\begin{array}{l}\text { Infected shrimps show } \\
\text { black/brown gills or } \\
\text { appendage discoloration } \\
\text { or cottony appearance. }\end{array}$ & $\begin{array}{l}\text { Renamycin } 5 \mathrm{~g} / \mathrm{kg} \text { feed } \\
\text { Oxytetracycline } 1 \mathrm{~g} / \mathrm{kg}\end{array}$ & $42-45$ \\
\hline
\end{tabular}

Effect of aqua-drugs and chemicals on shrimp production: In Khulna region (Botiaghata upazilla) shrimp production was the highest $2800 \mathrm{~kg} / \mathrm{acre}$ in probiotics, aqua-drugs and chemicals used ponds, whereas, in control ghers and Lime-feed used ghers, shrimp production was $741 \mathrm{~kg} / \mathrm{ha}$ and $1679 \mathrm{~kg} / \mathrm{ha}$ respectively. In Khulna (Dacope upazilla) shrimp production was $543 \mathrm{~kg} / \mathrm{ha}$ in control ghers, however in lime and feed used production was $1358 \mathrm{~kg} / \mathrm{ha}$ whereas, in aqua-drugs and chemical treated shrimp production was $3458 \mathrm{~kg} / \mathrm{ha}$. In Khulna (Rupsha upazilla) shrimp production was $617 \mathrm{~kg} / \mathrm{ha}$ in control ghers, whereas, $1482 \mathrm{~kg} / \mathrm{ha}$ in Lime and feed however in aqua-drugs and chemicals treated shrimp production was $3853 \mathrm{~kg} / \mathrm{ha}$ (Table III). 

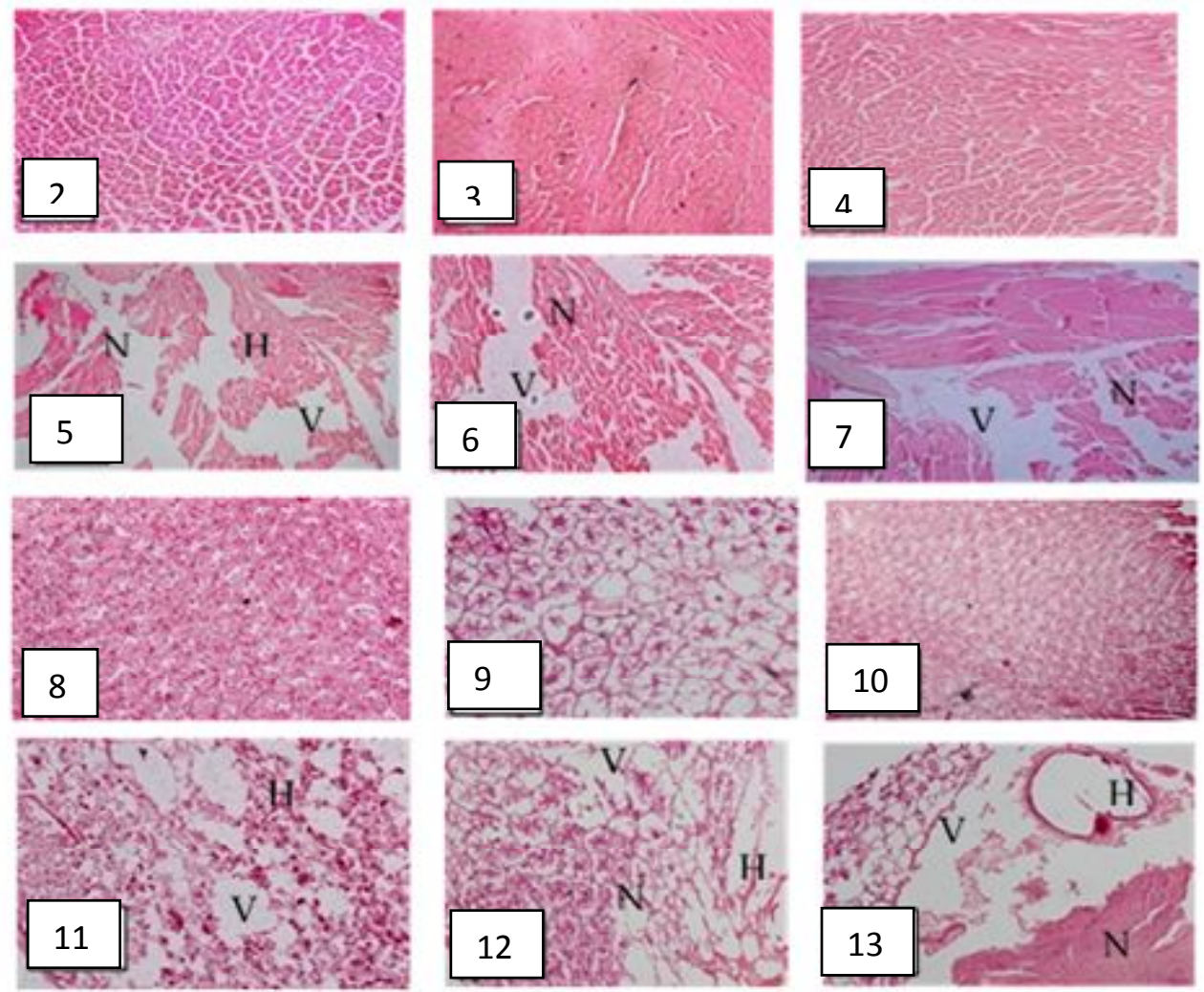

Fig.2-4. Cross section of normal muscle of shrimp (H \& E x 120) collected from Botiaghata, Dacope and Rupsha, respectively during summer.

Fig.5-7. Cross section of muscle of shrimp (H\&E x 120) collected from Botiaghata, Dacope and Rupsha, respectively during winter season having wide vacuum $(\mathrm{V})$, severe necrosis $(\mathrm{N})$ and haemorrhage (H).

Fig.8-10. Photomicrograph of hepatopancreas of shrimp (H \& E x 120) collected from Botiaghata, Dacope and Rupsha, respectively during summer.

Fig.11-13. Section of hepatopancreas of shrimp (H \& E x 120) collected from Botiaghata, Dacope and Rupsha, respectively showing vacuum $(\mathrm{V})$, necrosis $(\mathrm{N})$ and haemorrhage $(\mathrm{H})$ during winter.

Table III. Effect of aqua-drugs on shrimp production in study areas

\begin{tabular}{l|c|c|c}
\hline \multirow{2}{*}{ Study areas } & \multicolumn{3}{|c}{ Production of shrimp and prawn (Kg/ha) } \\
\cline { 2 - 4 } & Control & Lime and feed & Drugs, chemicals and feed \\
\hline Botiaghata & 741 & 1679 & $6916^{*}$ \\
\hline Dacope & 543 & 1358 & 3458 \\
\hline Rupsha & 617 & 1482 & 3853 \\
\hline \multicolumn{2}{c}{$*$ Probiotics and drugs used }
\end{tabular}




\section{EFFECT OF AQUA-DRUGS AND CHEMICALS ON SHRIMP HEALTH AND PRODUCTION}

\section{Discussion}

In the present study, in Khulna region several shrimp diseases like White Spot Disease (WSD), Bacterial disease, Cotton Shrimp Disease, Black spot disease, Surface Fouling Diseases and Black Gill Disease were found. Hasan et. al. (2015) observed that several shrimp diseases like White Spot Disease (WSD), Bacterial disease, Cotton Shrimp Disease and Black Gill provided impact on shrimp production. In Khulna region farmers used different types of drugs for the treatment of Viral, Bacterial and Protozoan diseases. The farmers used Malachite green, Methylene blue, Bleaching powder and Potassium permanganate for the treatment of WSD, however, no recovery was observed. Islam (2013) mentioned that Basudin, Methylene blue, Bleaching powder, Oxytetracycline, Potash were used for WSSV treatment in Khulna region. According to the authors, Methylene blue, Oxytetracycline did not provide any positive result for recovery of WSSV disease, whereas, some improvement was noticed while used potash and bleaching powder in the ghers. It was recorded that farmers of Khulna region used Potassium permanganate, Eco solution, Methylene blue, Basudin and Timsen for the treatment of YHD which had an average recoveryof $20-25 \%$. Farmers used Renamycin, Oxytetracycline, Lime, Salt, and Potassium permanganate for the treatment of bacterial diseases which had an average recovery of 55-60\% in Khulna region. Farmers of Khulna region used Formalin, Oxolinic acid, Sarafloxacin, Renamycin, Oxytetracycline, lime and salt which had an average recovery of 35$40 \%$ on cotton shrimp disease but had no positive impact on Black Gill Disease.

From the present study it was observed that, clinically shrimp of Khulna region (Dacope, Botiaghata and Rupsha) were normal and healthy except some yellowish color in nontreatedghers, whereas, in chemical treated ghers shrimps ware slightly yellowish with faded and discolored. Clinically health condition of shrimp of Batiaghata region was improved than Dacope region. In Dacope upazilla shrimps were normally healthy in non-treated ghers, however, shrimp of WSD affected had white spots and slight discoloration in treated ghers. Clinically shrimps in Botiaghata upazilla were healthy in chemical treated pond. In Rupsha upazilla shrimps were normal and healthy with slight yellow-greenish color in chemical treated ponds. Shrimp from Botiaghata were affected by black gill disease in non-treated ponds. Algae were found on the body surface of shrimps in treated ponds from Botiaghata. In Dacope upazilla shrimps were affected by Zoothumnium in ghers. In Rupsha shrimps were affected by black shell disease in control ponds. After post-harvest shrimps were reddish in ghers of Dacope upazilla. Aqua-drugs treated shrimp had yellowish-brown color in ponds of Rupsha. It was discovered WSSV spread to other coastal districts affecting extensive shrimp farms (Flegel, 1996). In 2001, the disease once again caused the collapse of shrimp production in both Cox's Bazar and Khulna regions, the disease has not yet been completely eradicated and can still cause havoc for shrimp producers (DoF 2005). Hasan et al. (2015) mentioned that, in Dacopeupazilla shrimps were healthy in nontreated ghers, however, shrimp of WSD affected had white spots and slight discoloration in treated ghers. The author further mentioned that in Koyraupazilla shrimps were normal and healthy with slight yellow-greenish from control gher, whereas, WSD affected shrimp were found after rain. Shrimp from Rampal were slight greenish fade in control gher, however, yellow fade color in treated gher (Ahmed et al. 2015). Shrimp from Rampal were slight greenish fade in control gher, however, yellow fade color were seen in treated ghers (Hasan et al. 2015). 
From histological observations it was observed that, muscle of control shrimp (non treared) of all the investigated areas of Khulna region were almost normal except some vacuums. However, in the drugs treated shrimp of all the investigated areas of Khulna regions it was observed that, muscle of shrimp from Batiaghata, Dacope and Rupsha were normal in summer season, however, there were some vacuums, hemorrhage and necrosis in the rainy season. In the autum season muscle of shrimps were almost normal in the study areas. In cross section of muscle of shrimp in winter season, there were severe pathology like vacuums, hemorraghe and necrosis in Botiaghata, Dacope and Rupsha. Ahmed et al. (2015) mentioned that, muscle of control shrimp of all the investigated areas of Cox's Bazar and Khulna regions were almost normal except there were some vacuums in control shrimp muscle. However, in the drugs treated shrimp of all the investigated areas of Cox's Bazar and Khulna regions there were remarkable pathological changes like necrosis, vacuums, inclusion bodies and pyknotic cells.

Photomicrograph of hepatopancreas of shrimp were normal in the summer season in the study areas. There were remarkable pathological changes like vacuums, necrosis and hemorrhage from Botiaghata, Dacope and Rupsha during rainy season. In the autum season the hepatopancreas of shrimp were almost normal except mild vacuums in Botiaghata and Dacope but there were severe vacuums and necrosis in hepatopancreas of shrimp from Rupsha. There were numerous vacuums, necrosis and hemorrhage in hepatopancreas from study areas in the winter season. Hasan et al. (2015) mentioned that shrimp and prawn in control ghers and ponds were normal from Koyra except some vacuums in hepatopancreas from Narail and Rampal and minute inclusion bodies of shrimp hepatopancreas from Dacope. In treated ghers the author mentioned that, shrimp hepatopancreas had remarkable pathological changes like vacuums, necrosis and minute inclusion bodies from Pekua and Dacope and also showed vacuums, pyknotic cell and minute inclusion bodies from hepatopancreas of shrimp at Rampal, whereas, minute inclusion bodies, hemorrhage and pyknotic cells were in hepatopancreas of shrimp from Koyra.

From the present study it was observed that the overall impact of use of aqua-drugs in case of shrimp health and production was very significant. Due to the use of aqua-drugs the average production of the shrimp had increased but the health condition of the cultured shrimp had deteriorated. Shrimp production recorded in Khulna region (Botiaghata upazilla) was the highest $(6916 \mathrm{~kg} / \mathrm{ha})$ in probiotics, aqua-drugs and chemicals used ponds, whereas, in control ghers and lime-feed used ghers, shrimp production was $741 \mathrm{~kg} / \mathrm{ha}$ and $1679 \mathrm{~kg} / \mathrm{ha}$ respectively. In Khulna (Dacope upazilla) shrimp production was $543 \mathrm{~kg} / \mathrm{ha}$ in control ghers, however, in lime and feed used ponds production was $1358 \mathrm{~kg} / \mathrm{ha}$, on the other hand in aqua-drugs and chemical treated ponds shrimp production was $3458 \mathrm{~kg} / \mathrm{ha}$. In Khulna (Rupsha upazilla) shrimp production was $617 \mathrm{~kg} / \mathrm{ha}$ in control ghers, whereas, $1482 \mathrm{~kg} / \mathrm{ha}$ in lime and feed used one. In aqua-drugs and chemicals treated ponds and ghers, shrimp production was $3853 \mathrm{~kg} / \mathrm{ha}$. Hasan (2014) investigated that in Khulna region (Dacope upazilla) shrimp production was the highest (5187 $\mathrm{kg} / \mathrm{ha}$ ) in probiotics, aqua-drugs and chemicals used ghers, whereas, in control ghers and limefeed used ghers, shrimp production was $296 \mathrm{~kg} / \mathrm{ha}$ and $642 \mathrm{~kg} / \mathrm{ha}$ respectively. In Rupsha, a shrimp farmer named Abdus Sattar achieved $1358 \mathrm{~kg} / \mathrm{ha}$, whereas, another farmer, Mozid achieved only $494 \mathrm{~kg} / \mathrm{ha}$. This is due to fact that Abdus Sattar used aqua-drugs in his shrimp gher, whereas, Mozid used no inputs. Thus it could be mentioned here that aqua-drugs played role in increased shrimp production in the Khulna region of Bangladesh. 
It was observed that, there was distinct effect of aqua-drugs and chemicals on health and production of shrimp in coastal aquaculture of Bangladesh. Through clinical observations it could be mentioned that, shrimps were affected in non treated ghers and ponds in study area and disease free were found in most of the treated farms. However, in histological observations, shrimp muscles and hepatopancreas in drug treated ghers had pathological changes like necrosis, vacuums and hemorrhages. Whereas, almost normal structure except some vacuums and necrosis were observed in shrimp of non-treated ghers. The highest production of shrimp in probiotics and drug treated ponds were recorded as $6916 \mathrm{~kg} / \mathrm{ha}$, whereas, it was $543 \mathrm{~kg} / \mathrm{ha}$ in non-treated ghers. From the present study, it could be stated that, Bangladesh aquaculture has been influenced by aqua-drugs and chemicals which had positive impacts on aquaculture production and disease recovery. However, some pathological changes were observed in shrimp organs where aqua drugs and chemicals were applied. Thus care should be taken on use of aqua drugs; if possible doses and quantitis of drugs for diseases should be reduced. In coastal regions the recorded diseases of shrimp were WSD, YHD, External Fouling, MBVD, Black gill disease and Bacterial diseases. Farmers obtained $15-20 \%$ recovery by using potassium permanganate, Eco solution, Methylene blue, Basudin and Timsen on YHD and obtained 55-60\% recovery by using Renamycin, Oxytetracycline, Lime, Salt, and Potassium permanganate for the treatment of bacterial diseases. From histological observations shrimp muscle had pathologies like hemorrhage, vacuum, necrosis in mentioned organs in aqua-drugs treated ponds. The highest production of shrimp in probiotics and drug treated ghers were recorded $6916 \mathrm{~kg} / \mathrm{ha}$, whereas, $543 \mathrm{~kg} / \mathrm{ha}$ in non-treated ghers. Thus it could be concluded that aqua-drugs and chemicals played significant role on shrimp health and production in coastal regions of Bangladesh.

\section{Literature Cited}

Ahmed, G.U., M.T. Hasan, M.A.R. Faruk, M.K. Rahman and M.N. Hoque, 2015. Aqua-drugs and chemicals: impact on fish health and production in Mymensingh, Bangladesh. Res. Agric. Livest. Fish., 2(1): 161-168.

Ahmed, G.U., M.A.R. Faruk and M. Shamsuddin, 2012. Impact of aqua drugs and chemicals on health of fish. $5^{\text {th }}$ Fisheries Conference and Research Fair, 2012. Bangladesh Fisheries Research Forum (BFRF). 39p.

Banglapedia, 2014. Coastal Aquaculture in Bangladesh. en.banglapedia.org $>$ title $=$ Coastal Aquaculture, 28 April 2014.

BFRI, 1999. Fish diseases: prevention and control. Bangladesh Fisheries Research Institute, Circular leaflet no 6. 2nd Edition. 7p

DoF, 2005. Fish Fortnight (leaflet). Department of Fisheries, Ministry of Fisheries and Livestock, Dhaka, Bangladesh.

Faruk, M.A.R., M.J. Alam, M.M.R. Sarker and M.B. Kabir, 2004. Status of fish diseases and health management practices in rural freshwater aquaculture of Bangladesh. Pakistan J. Biol. Sci., 7: 20922098.

Flegel, T., 1996. A turning point for sustainable aquaculture: White Spot virus crisis in Asian Shrimp culture, J. Aquacult., 6: 29-34.

Hasan, M.T., G.U. Ahmed, M.M. Rahman and M.N. Alam, 2015. Study on the effect of aqua-drugs and chemicals on (Macrobrachium rosenbergii) in Narail, Bangladesh. Asian J. Medic. Biol. Res., 1: 8994.

Islam, K.R., 2013. Study on impact of aqua drugs and chemicals on shrimp health and production in Bangladesh. MS Thesis, Department of Aquaculture, Bangladesh Agricultural University, Mymensingh, Bangladesh. 


\section{JAHID HOSSAIN et al.}

Karim, M. and J. Stellwagen, 1998. Final Report on Fourth Fisheries Projects: shrimp aquaculture (Preparatory phase for National development Program). Department of Fisheries, Ministry of Fisheries \& Livestock, Bangladesh.

Khan, M.R., M.M. Rahman, M. Shamsuddin, M.R. Islam and M. Rahman, 2011. Present status of aqua drugs and chemicals in Mymensingh district. J. Bangladesh Soc. Agril. Sci. Technol., 8: 169- 174.

Mahmud, A.N., M.R. Hasan, M.B. Hossain and M.H. Minar, 2012. Proximate composition of fish feed ingredients available in Lakshmipur region, Bangladesh. Am. Euro. J. Agril. Env. Sci., 12(5): 556560.

Sarker, M.R., K. Rukshana, M.J. Alam, M.M. Rahman, Z. Ferdous, M.M. Ali and M.R. Chaklader, 2014. Drugs and chemicals used in aquaculture activities for fish health management in the coastal region of Bangladesh. Int. J. Life Sci. Bt. Pharm., 3(4): 49-58.

Stentiford, G.D., K. Sritunyalucksana, S. Apisawetakan, A. Boon-nat, B. Withyachumnarnkul and T. Flegel, 2006. A new RNA virus found in black tiger shrimp P. monodon from Thailand. Virus Res., 118: $31-38$.

Subasinghe, R.P., U. Barg and A. Tacon, 1996. Chemicals in Asian aquaculture: need, usage, issues and challenges. Southeast Asian Fisheries Development Center, Aquaculture Department Tigbauan, Iloilo, Philippines, pp. 1-6 